Open Access

\title{
The effect of technology-exploration on product innovation: an analysis based on Korean manufacturing SMEs
}

\author{
Hojin Lee, Sangyoon Cha and Heejun Park
}

\footnotetext{
* Correspondence: h.park@yonsei.ac.kr Department of Information and Industrial Engineering, Yonsei University, 120-749, Shinchon-Dong, Seodaemoon-Gu, Seoul, Korea
}

\begin{abstract}
Today, fierce competition drives firms in their continual efforts to introduce products with a higher degree of novelty into the market. There is a growing need to understand important activities so as to achieve product innovation. This empirical study demonstrates the effect of technology-exploration, including outsourcing R\&D, external networking, customer involvement, and inward IP licensing, on product innovation, especially considering the degree of the novelty of the manufactured products. Using data from a sample of small and medium Korean manufacturing firms, our results show that technology-exploration are crucial determining factors as to whether low or higher degree of novelty is achieved in product innovation. The positive impact of higher degree of innovation novelty comes from customer involvement and outsourcing R\&D. In addition, customer involvement has positive impact only on low degree of innovation. Other practices have no impact on either low or high degree of novelty in product innovation.
\end{abstract}

Keywords: Open innovation, Technology-exploration, Product Innovation, SMEs

\section{Background}

Traditionally, when firms are seeking product innovation, they mainly rely on internal knowledge and technology, along with internal R\&D competency, which can translates to competitiveness in the market. Firms with large-scale R\&D centers are more likely to have the ability to produce the valuable knowledge and technology necessity for product innovation [1]. However, the innovation environment have changed, making it is difficult for firms to achieve competitive product innovation using only the knowledge and technology obtained from internal R\&D [2, 3].

Due to the rapid technological development and more diversified customer needs, firms can no longer dominate the market with only one product for a long period of time. To meet various customer needs and to adapt rapid changes in the market, firms have to capitalize not only on internal expertise but also on all other available means, such as external knowledge and the convergence or integration of technology, in order to survive in the fast changing market $[2,4,5]$.

Although there have been multiple studies of product innovation to enhance firms' competitiveness so that they may adapt to the fiercely competitive environment, most of studies are targeted for large scale firms. In many countries worldwide, small and

(c) 2016 The Author(s). Open Access This article is distributed under the terms of the Creative Commons Attribution 4.0 International License (http://creativecommons.org/licenses/by/4.0/), which permits unrestricted use, distribution, and reproduction in any medium, provided you give appropriate credit to the original author(s) and the source, provide a link to the Creative Commons license, and indicate if changes were made. 
medium enterprises (SME) represent a high proportion of the national economy. By targeting Korean manufacturing SMEs, this study attempts to examine how to obtain and utilize external knowledge, necessary for innovation, and affects product innovation in the evolving market.

SMEs are of great importance in the Korean economy, representing $99 \%$ of the total number of businesses and $87 \%$ of the entire employment [6]. In terms of manufacturing in Korea, they account for nearly $99.5 \%$ of all manufacturers [6]. Nevertheless, the business environment of Korean manufacturing SMEs is relatively poor [6]. They represent only $46.4 \%$ of manufacturing output and $49.2 \%$ of the total value-added amount [7]. Worse yet, they are much weaker when competing with the larger manufacturing firms, as evidenced by the value-added rate of productivity per employee being merely $30 \%$ of that of larger manufacturing firms [8]. The growth imbalance between manufacturing SMEs and manufacturing large firms was and is a result of the government's growth-oriented policy, which concentrates on capital for a minority of larger firms to catalyze high-speed growth.

One of the strong competitive edges enabling these manufacturing SMEs to grow, despite the unfavorable business environment (compared with their larger counterparts), has been the implementation of low wages. Recently, however, Korea has seen the overall labor cost rising and has thus lost the low-wage advantage, owing in part to the growth of manufacturers in China and Southeast Asia. To survive under such conditions, Korean manufacturing SMEs must bring high-quality products into the market through product innovation [7].

To create knowledge and technology for product innovation, the capability of internal $R \& D$ is important. At present however, Korean manufacturing SMEs are experiencing a deterioration of the profits originally gained from their low-wage competitiveness along with steadily increasing incidental expenses. As a result, these manufacturing SMEs have difficulty investing in internal R\&D. As these circumstances continue, they will continue to undergo hardships when seeking to acquire internal knowledge and technology [7].

Despite these hardships, their small scale can also serve as a positive force for product innovation. By having a low degree of bureaucracy, they can rapidly make decisions that can lead to quick and flexible responses to external changes in the market $[9,10]$. Also, by facilitating changes with external collaborative partners and by adjusting their trade volume, they can use their networks more effectively [11, 12].

Moreover, even if they have a product that dominates the market, they are less likely to maintain the advantages of their existing market dominance than larger companies. When firms are in a dominant position in the market, they are likely to refuse to change and try to maintain their position in the existing market, thereby neglecting the importance of innovating and eventually falling behind in the market. However, manufacturing SMEs are less likely to try to maintain the advantages of their existing market even if they have a product that dominates the market, thereby continually innovating to keep up with the dynamic environment of the market. Thus, they can cope with market changes more sensitively and thus become more able to meet customer needs faithfully. Many studies have presented the use of external knowledge, resources, and human power as means of utilizing SMEs' strengths and as factors that offset their insufficient capabilities in internal R\&D [11-14]. 
Through external networking with larger companies, other SMEs, universities, and public or private research institutes, manufacturing SMEs can make use of these sources of external knowledge and technology for product innovation or can engage customers in the process of product innovation through the use of their customers' knowledge. These are good alternatives with which to achieve product innovation by complementing the deficient capabilities of the internal R\&D of manufacturing SMEs with their external networking capabilities [15].

Relevant studies define the various activities of firms which secure external knowledge and technology collectively as "technology exploration." Although many related studies have been carried out, few if any have explored the effectiveness of technology exploration. This study will examine the impact that technology exploration has on product innovation for manufacturing SMEs, with the primary target being Korean manufacturing SMEs with less than 500 employees.

\section{Literature review and research model development}

\section{Product innovation}

Expanding worldwide competition, fragmenting markets, and emerging technologies mean that established firms must renew themselves continually by transforming stagnant businesses and creating new wealth through new combinations of resources. Successful new products and services are critical for many organizations. In particular, manufacturing firms need to develop new products to survive and prosper in a changing business environment [16].

Four Innovations have been defined as process, marketing, organizational, and product-related innovation [17]. Process innovation is the implementation of a new or significantly improved production or delivery method $[17,18]$. This includes significant changes in techniques, equipment and/or software. It can be intended to decrease unit cost of production or delivery, to increase quality, or to produce or deliver new or significantly improved products $[17,18]$. Marketing innovation is the implementation of a new marketing method involving significant changes in product design or packaging, product placement, product promotion or pricing $[17,18]$. It aimed at better addressing customer needs, opening up new markets, or newly positioning a firm's product on the market, with the objectives of increasing the firms' sales [17, 18]. Organizational innovation is the implementation of a new organizational method in the firm's business practices, workplace organization or external relations [17, 18]. It can be intended to increase a firm's performance by reducing administrative costs or transaction costs, improving workplace satisfaction, labor productivity, gaining access to non-tradable assets, such as non-codified external knowledge or reducing costs of supplies [17, 18]. Lastly, product-related innovation is the introduction of a good or service that is new or significantly improved with respect to its characteristics or intended uses [17, 18]. This includes significant improvements in technical specifications, components and materials, incorporated software, user friendliness or other functional characteristics [17, 18].

Among these types of innovations, product innovation is important for manufacturing firms to adapt changes in technologically competitive in the market. This type of innovation has been recognized as a primary engine of firm's innovation, and it is closely linked to the development of new products in manufacturing industries [16]. 
Through product innovation, manufacturing firms can maintain or build their market share in both mature and new businesses and can find new sources of synergy among their resources [16]. We focus on product innovation as reflecting the characteristics of activities in the manufacturing industry and attempt to capture product innovation performance.

Taxonomies of novelty of product innovation span from radical to incremental innovation according to newness of the innovation [19].

Radical innovation is defined as the propensity of a firm to introduce new products that incorporate substantially different technologies from existing products and that can fulfill key customer needs better than existing products [20]. At some point during the maturity of an existing technology, a new technology emerges, which leads to a new product. This process is known as a technological breakthrough. A new technology offers few consumer benefits when first introduced, rapidly increasing consumer benefits as it develops, and slowly increasing consumer benefits as the technology matures. To achieve radical innovation, firms need to make a considerable investment in $R \& D$, and the chances of success are lower as the rewards become greater [21]. The effects of radical innovation on firms' profits can be large, positive, and long-lasting [22].

Incremental innovations involve relatively minor changes in technology, such as changing the packaging of existing products. Therefore, they provide relatively low incremental customer benefits.

To achieve incremental innovation, firms put in less effort compared to radical innovation, but the rewards are smaller [21]. Firms can achieve incremental innovation through a new structure that screens out information unrelated to the important task and routines that carry out repetitive tasks efficiently [23]. If a firm's new product dominates the market, the firm can focus on 'fine-tuning' product by means of incremental improvements which are informed by a variety of sources of innovation. As the product matures and the market expands, the number of sources of specific knowledge of various aspects of technology increases. In other words, incremental innovations are likely to be successful when using knowledge from various external sources.

\section{Technology-exploration}

Technology-exploration refers to practices which enable firms to acquire new knowledge and technologies from outside through customer involvement, external networking, external participation, outsourcing R\&D, and the inward licensing of IP [15, 24]. Technology-exploration activities are defined in Table 1.

Customer involvement is an important practice to inform internal innovation processes through external customers' needs [4]. An important key in the innovation process is to release products or services that meet customer needs for the firm's survival [25].

Involving the customer provides a correct innovation direction and enables the firm to reduce the investment costs, time, and diversity of uncertainty that may occur in the innovation process $[26,27]$.

Recently, customers are increasingly demanded as not just simply being as passive adopters but as active participants. Therefore, firms need to fully understand their reflected ideas and evaluations in the product innovation process. 
Table 1 Technology-Exploration Definitions

\begin{tabular}{|c|c|}
\hline Practice & Definition \\
\hline \multicolumn{2}{|c|}{ Technology exploration } \\
\hline $\begin{array}{l}\text { Customer } \\
\text { involvement }\end{array}$ & $\begin{array}{l}\text { Directly involving customers in your innovation processes, for example by active, market research } \\
\text { to check their needs, or by developing products based on customers' specifications or } \\
\text { modifications of products similar to those produced at the firm. }\end{array}$ \\
\hline $\begin{array}{l}\text { External } \\
\text { Participation }\end{array}$ & $\begin{array}{l}\text { Equity investments in new or established enterprises in order to gain access to this knowledge or } \\
\text { to obtain other synergies. }\end{array}$ \\
\hline $\begin{array}{l}\text { External } \\
\text { networking }\end{array}$ & $\begin{array}{l}\text { Drawing on or collaborating with external network partners to support innovation processes, for } \\
\text { example for external knowledge or human capital. }\end{array}$ \\
\hline $\begin{array}{l}\text { Outsourcing } \\
\text { R\&D }\end{array}$ & $\begin{array}{l}\text { Buying R\&D services form other organizations, such as universities, public research organizations, } \\
\text { commercial engineers or suppliers. }\end{array}$ \\
\hline $\begin{array}{l}\text { Inward IP } \\
\text { Licensing }\end{array}$ & $\begin{array}{l}\text { Buying or using intellectual property, such as patents, copyrights or trademarks, of other } \\
\text { organizations to benefit from external knowledge. }\end{array}$ \\
\hline
\end{tabular}

Customers influence the development or improvement of products by providing complementary knowledge, establishing a precise set of user requirements, and providing a source of solicited information on new evolving needs [28]. The type of customer involvement is different depending on product innovation type, for instance whether a new product is being created or an existing product is being improved.

Incremental product innovation simply requires the gathering of customer requests or complaints. Firms can achieve an improvement to their current product or technology. On the other hand, radical product innovation requires applying customer knowledge actively to innovation process. When firms encounter a customer's innovative concept and have the appropriate technological competence and strategies to realize the customer's radically new concepts and actively accept their new concepts, they can achieve the development of a radically new product. Customers contribute to product innovation in the role of an inventor or a co-producer of innovation [29]. Particularly, manufacturing SMEs can have personal and close relationships with customers owing to their small scale. This can also give them a high capacity for customization [30]. Strengths from a small firm size are scarce bureaucracy, clannish structures, and low costs of internal communication [12]. These strengths make it easier for manufacturing SMEs to achieve product innovation reflecting their customers' ideas.

External participation is a practice in which firms invest equity in a new or established business in order to gain access to the knowledge of the business or to obtain other synergistic effect. Firms may invest in start-ups and other businesses to keep an eye on potential opportunities [3]. Such equity investments provide opportunities to increase external collaboration further in case their technologies prove to be valuable [31].

We refer to external corporate venturing as the creation of a new business by firms in which a firm leverages external partners in an equity or nonequity interorganization relationship. Firms utilize several governance modes to conduct their external corporate venturing activities. Governance modes include corporate venture capital (CVC) investments, nonequity alliances for the development of new business ventures, joint ventures, and acquisitions of entrepreneurial ventures. CVC investments and joint ventures among these governance modes work in the equity alliance mode with external partners; thus, they are defined as types of external participation [32].

CVC investments are defined as external equity investments made by established firms in privately held entrepreneurial start-ups [33]. Joint ventures refer to 
partnerships in which the formation of a new legal entity and organization takes place when two companies pursue a business opportunity or new knowledge together. Both governance modes utilize corporate investors potentially to access new knowledge that would not otherwise be available by ensuring an equity relationship with start-ups or established firms, and they enable firms to realize a financial gain as well as potential strategic benefits such as the learning of the market and technologies [34]. Access to new external knowledge through external participation can influence knowledge creation within investor firms and can be an important opportunity for firms to explore new ideas. Thus, an increase in external participation investment will be associated with increased future product innovation [35].

However, external participation cannot be used as an independent variable in our study. CVC investment and joint ventures are only relevant for relationships with large, established firms because firms need large amounts of funds for equity investments in external organizations [36]. However, our sample firms are manufacturing SMEs. Therefore, most of them rarely invest in external participation. Thus, it is difficult to acquire data related to external participation in a survey method. Although external participation influences product innovation, external participation is unsuitable for use as an independent variable in this study. Therefore, we eliminated external participation from our study model.

External networking is another important practice which is consistently associated with all activities to acquire and maintain connections with external sources of social capital, including individuals and organizations. As such, it comprises both formal collaborative projects and informal networking activities [5]. Networks allow firms rapidly to fill in specific and necessary knowledge without spending enormous amounts of time and money to develop or acquire knowledge internally. Firms can acquire appropriate tacit knowledge of a partner and procure codified knowledge through an external network. Alliances between non-competing firms have become a popular method of reducing investment costs and acquiring technological capabilities [37]. Specifically, as technology becomes so complex that it cannot be handled by one firm alone, relevant knowledge is ever more scattered across various firms, and collaboration between firms is increasingly regarded as an important factor for success [38, 39].

Firms can create new knowledge through a combination of knowledge from diverse sources of knowledge [40]. New knowledge can help firms address established problems using a new approach that combines the old and the new and can influence product innovation by supporting, complementing, or augmenting their internal R\&D capabilities [41].

Collaborating with different types of partners on $R \& D$ represents knowledge network diversity or diverse sources of knowledge. Network diversity facilitates innovative process by enabling firms to create novel associations and linkages [42]. It raises the likelihood of achieving product innovation due to the amount and variety of knowledge that is shared [5, 43]. In particular, many researchers have focused on the relationship between the diversity of the network and product innovation. Recent works suggest that using a wide range of external actors and sources should help a firm to achieve and sustain product innovation [2]. However, manufacturing SMEs are not fully capable of identifying and evaluating new knowledge owing to resource constraints; thus, they are poor in their use of external 
information. This lack of information and the small scale of the firm result in SMEs having low negotiation power [14]. Moreover, many manufacturing SMEs' information search activities are likely to be prohibitively costly or misdirected due to the absence of functional specialists or a lack of high and broad levels of internal competence $[9,11]$. We study whether external network diversity influences product innovation in manufacturing SMEs even with these constraints.

Numerous manufacturing firms are increasingly outsourcing R\&D to cope with the rapidly changing technology and market dynamics [44]. Outsourcing R\&D refers to the practice of firms entrusting the performance of an activity that was performed formerly in-house to an external entity [24]. Firms can enjoy a few benefits from outsourcing R\&D. They can leverage the know-how and key development strengths of partners for faster time-to-market. They also can enlarge their innovation capacity with new knowledge and experience across the globe and get new and innovative products to the market faster with enhanced efficiency [45]. Outsourcing R\&D may increase a firm's strategic flexibility and force them to cope with the dynamics of their environment [46]. If an external shock occurs, firms are better able to deal with it by simply increasing or decreasing the volumes of investment in outsourced R\&D or by switching from one partner to another [47]. Particularly, if a firm's size is small, the firm may be more flexible in terms of adjusting outsourcing $R \& D$ plans due to its small scale. Thus, manufacturing SMEs may also find it easier to adjust outsourcing R\&D to ensure an optimal innovative result [48].

Outsourcing $R \& D$ is a central part of scientific or innovative research. Types of organizations that outsource R\&D include universities, government labs, independent R\&D organizations, suppliers, and other companies. Manufacturing SMEs can also acquire the scientific and innovative knowledge necessary to develop radically new products from organizations [49]. The knowledge and technology acquired from them complement the lack of internal R\&D capability and have an influence on product innovation. If a firm has high organization capacity to integrate outsourced knowledge and technology into internal knowledge, the effects that the outsourced knowledge and technology have on product innovation will be increased [50].

With the advent of the information revolution, skills and knowledge have become the only sources of a sustainable long-term competitive advantage. Intellectual property lies at the center of a modern company's odds of economic success or failure [51]. The rising importance of intellectual property can be seen in the earnings gained from the licensing of technology. In the past, firms were willing to share their technology, as it did not appear to be a source of their success and could not be sold for much in any case. However, knowledge-based industries are important in their own right, and firms can buy or license external knowledge through IP, including the licensing of patents and copyrights or trademarks at a lower cost. Therefore, firms are no longer willing to share their knowledge and technology without being compensated for it. Technology licensing allows firms to obtain relatively fast and inexpensive access to new and more advanced technologies. The manufacturing SMEs in our study can also internally develop and create new knowledge using inward IP licensing. With inward IP licensing, manufacturing SMEs can accumulate and strengthen their technological capability from the search and use of external technology [52]. This will result in the achievement of greater product innovation [51]. Inward licensing can be an alternative means of 
internal $R \& D$ to develop a new product and examine the factors that affect firms' propensities or intentions to adopt inward technology licensing as a new product development method. Thus, valuable knowledge from IP licensing influences product innovation [51].

All of the arguments thus far lead us to argue that firms which carry out technologyexploration activities are likely have an upper hand in achieving product innovation. We can hypothesize that technology-exploration including external network, external participation, outsourcing R\&D, customer involvement, and inward IP licensing to have an impact on product innovation.

\section{Methods}

\section{Samples}

The data for the analysis were drawn from STEPI (the Science and Technology Policy Institute) to support Korean policymakers in an effort to enhance national competitiveness. STEPI covers a wide range of Korean manufacturing firms in all industry sectors. The survey used here was implemented in 2008 and was based on a manual (a set of integral guidelines for the collection of innovation data; see OECD, 2005) [17]. The Oslo manual distinguishes innovation as either based on a product, process, organization or marketing innovation $[17,53]$. Oslo manual is technology innovation guideline for small business [17]. This guideline contains seven characteristics: objectives and scope of manual, needs for the measurement of innovation, basic definitions, TPP innovation activities, institutional classification, measuring aspects of the innovation process, measuring the expenditure on innovation, and survey procedures [17]. We selected product innovation, as it is related to the development of new products and services. Respondents had to be employed in their current jobs for at least 5 years and involved in open innovation. Our sample targeted manufacturing SMEs with no more than 500 employees, and data was collected from 2005 to 2007. The sample contains manufacturing SMEs that tried to achieve product innovation through technology-exploration activities during the 3 years prior to the survey. Our final sample contains 1044 firms that remained in the survey for the 3 years. By analyzing data from STEPI's 'Technology Innovativeness Activity Report in 2008', the survey questionnaire separates into two groups as high and low using 0 and 1 in collected samples. The survey questionnaire binary asks "Did you launch following product innovation for last 3 years (2005-2007) in the market?" and it request to select out of three criterions which are: 1 . Launch new product completely differs from existing product, 2. Launch highly improved product compared to existing product, and 3. None of these are applicable. Criterion number 1 interprets 'high' product innovation performance; number 2 interprets 'low' product innovation performance, and number 3 interprets insignificant. We defined these criterions as dummy variables. If respondents answered 'yes', either criterion 1 or 2 , then it values ' 1 ', and if they answered 'no', either criterion 1 or 2 , then it values ' 0 '. We rejected answers such as 'no' for all criterions because the data is insignificant for analyzing this research. Thus, by filtering and interpreting respondents' data based STEPI's survey; we could separate and define High and Low product innovation performance measurement and innovated manufacturers. 


\section{Variables \\ Dependent variables}

Product innovation performance measurement has always been a difficult task for researchers and has been handled in different ways depending on the purpose of the research [54, 55]. This paper follows Liker's indicator [56] in that it uses a criterion based on the characteristics of the product innovation to distinguish a high or low degree of the newness of an example of innovation. We use two dichotomous variables to measure the degree of newness of product innovation.

(1)High indicates innovations with a higher degree of novelty. This is defined as radical innovation in the literature. It involves developing and introducing new products that can fulfill key customer needs better than currently existing products. It takes a value of 1 when a firm declares new product functions resulting from innovation; otherwise its value is 0 .

(2)LOW indicates an incremental product innovation. This is defined as incremental innovation in the literature. It involves minor improvements or simple adjustments of a current product. It takes a value of 1 for innovation with a lower degree of novelty (e.g., product innovation involving changes in design, presentation, or of any component); otherwise its value is 0 .

\section{Independent variables}

We constructed four variables to analyze the impact of technology-exploration activities on product innovation: (1) customer involvement (CI), (2) outsourcing R\&D (OUTRD), (3) external networking (EXNT), and (4) inward IP licensing (INIPLI). We eliminate external participation in this model as it is too difficult to acquire related data due to the fact that manufacturing SMEs generally do not invest in external participation activities such as corporate venture capital (CVC) investments or joint ventures.

The variable $\mathrm{CI}$ can have an integral value between 0 and 10 depending on the degree of customer participation and on how much the customer contributed to the process of product innovation. Customers contribute to product innovation by providing information related to their needs, participating in the development phase of technology, providing core technology solutions, and commercializing the innovative prototype or product.

We assigned different values for variables depending on the contribution to product innovation of each customer's participation methods. We designated variables to represent the customer's needs information, their level of participation in the development phase of the technology, their provided core technology solutions, and whether they commercialized the innovative prototype or product. These were given integral values of $1,2,3$, and 4 , respectively. If a firm undertakes customer involvement, it is possible to sum up the values according to this method and set the maximum CI variable to 10 . The variable OUTRD utilizes the ratio of outsourcing $R \& D$ investment costs to the total sales. Scales of investment, sales, and profits of firms vary with the characteristics of the industry field. In order to consider the bias in the scales depending on the characteristics of industrial fields, the investment ratio for outsourcing $R \& D$ investment was designated with a variable. Furthermore, the higher the investment ratio is, the more likely product innovation is affected. The EXNT variable, an integral value 
between 0 and 12, depends on the diversity of the collaborative networks of a firm. The degree of network diversity is related to creating the knowledge that affects product innovation. We use the number of external network categories in which manufacturing SMEs collaborate to analyze the effect of the external network on product innovation. The INIPLI variable takes its integral value from the sum of the number of license-in and license-buy events. Earlier research suggests that the knowledge and technology acquired from inward IP licensing contributes to developing the new knowledge needed for product innovation. This new knowledge may influence the product innovation of manufacturing SMEs.

\section{Control variables}

We include control variables for firm-specific characteristics of size, R\&D intensity, and globalization.

Size is measured by average sales (Sizes) during the 3-year sample period [57, 58]. The amounts of investment, employment, and utilization are different depending on a firm's size. This variable is designed to determine if this difference, depending on a firm's size, has an influence on product innovation. We included a control variable for the intensity of internal $R \& D$ ( $R \& D$ intensity) - the ratio of internal $R \& D$ expenditure to total sales-to explain the production of innovation [58]. This variable captures the notion of the absorptive capacity insofar as firms that conduct their own R\&D are more able to use externally available knowledge. Globalization is measured as the ratio of total exports to total sales (Glob) to show that exports and internationalization have positive significant effects on innovation [59]. Globalization is a variable that determines if the competition in the global market influences the demand for product innovation.

\section{Model specification}

We developed a model of the relationship between product innovation and open innovation practice using a bivariate probit model. As both dependent variables, HIGH and LOW, are dichotomous $(0,1)$, estimation models such as the logit or probit model would be appropriate [60]. However, as the error terms of the two models are likely to be correlated, an extension of the probit model known as bivariate probit [61] is usually a more appropriate estimator. The bivariate probit model has the following specifications:

$$
\begin{aligned}
& \mathrm{Z}_{\mathrm{i} 1}=\beta_{1} \mathrm{x}_{\mathrm{i} 1}+\varepsilon_{\mathrm{i}} 1 ; \mathrm{y}_{\mathrm{i} 1}=1 \text { si } \mathrm{z}_{\mathrm{i} 1}>0, \quad \mathrm{y}_{\mathrm{i} 1}=0 \text { si } \mathrm{z}_{\mathrm{i} 1} \leq 0, \\
& \mathrm{Z}_{\mathrm{i} 2}=\beta_{2} \mathrm{x}_{\mathrm{i} 2}+\varepsilon_{\mathrm{i}} 2 ; \mathrm{y}_{\mathrm{i} 2}=1 \text { si } \mathrm{z}_{\mathrm{i} 2}>0, \quad \mathrm{y}_{\mathrm{i} 1}=0 \text { si } \mathrm{z}_{\mathrm{i} 2} \leq 0 \\
& \left(\varepsilon_{\mathrm{i} 1}, \varepsilon_{\mathrm{i} 2}\right) \sim \mathrm{N}(0,0,1,1, \rho)
\end{aligned}
$$

This model produces estimates of the coefficient vectors for the two equations of $\rho$ (the correlation between the errors terms of the equations) and of the standard errors for these parameters. We can then test if the correlation between the equations is statistically significant and decide whether or not the bivariate estimator is the most appropriate model. If this correlation of the equations is not significant, a separate (univariate) probit estimation of the equations is preferable, as the bivariate probit model is less efficient. The bivariate probit model was estimated using the Stata 10 routine based on the simulated maximum likelihood method. The difference between the specifications of each model lies in the explanatory variables (open innovation practice: 
customer involvement, external networking, outsourcing R\&D, inward IP licensing). The model that includes all variables is the following model:

A higher degree of novelty of product innovation and an open innovation practice model:

$$
\begin{aligned}
& Z_{i 1}=\varepsilon_{1}+\beta_{1} \text { CI }+\beta_{2} \text { OUTRD }+\beta_{3} \text { EXNT }+\beta_{4} \text { INIPLI }+\beta_{5} \text { Sizes }+\beta_{6} \text { R\&D intensity }+\beta_{7} \text { Glob } \\
& y_{\mathrm{i} 1}=1 \text { si } \mathrm{z}_{\mathrm{i} 1}>0, \quad \mathrm{y}_{\mathrm{i} 1}=0 \text { si } \mathrm{z}_{\mathrm{i} 1} \leq 0
\end{aligned}
$$

A lower degree of novelty of product innovation and an open innovation practice model:

$$
\begin{aligned}
& \mathrm{Z}_{\mathrm{i} 2}=\varepsilon_{2}+\beta_{1} \text { CI }+\beta_{2} \text { OUTRD }+\beta_{3} \text { EXNT }+\mathrm{b}_{4} \text { INIPLI }+\beta_{5} \text { Sizes }+\beta_{6} \text { R\&Dintensity }+\beta_{7} \text { Glob; } \\
& \mathrm{y}_{\mathrm{i} 2}=1 \text { si } \mathrm{z}_{\mathrm{i} 2}>0, \quad \mathrm{y}_{\mathrm{i} 1}=0 \text { si } \mathrm{z}_{\mathrm{i} 2} \leq 0 \\
& \left(\varepsilon_{\mathrm{i} 1}, \varepsilon_{\mathrm{i} 2}\right) \sim \mathrm{N}(0,0,1,1, \rho)
\end{aligned}
$$

Note $: \mathrm{CI}=$ Customer Involvement, OUTRD $=$ Outsourcing $\mathrm{R} \& D$, EXNT = External Networking, INIPLI = Inward IP Licensing, Sizes = Average Sales, R\&D intensity = Intensity of internal R\&D, Glob = Globalization.

\section{Results}

Table 2 provides estimates of the impact of technology exploration activities, in this case customer involvement, external networking, outsourcing R\&D and inward IP licensing, on the degree of the novelty of product innovation. We used the bivariate probit model to test the impact of technology exploration with data from 2005 to 2007.

The error structures of the equations in both models were found to be very significantly correlated with the $\rho$ parameter. This shows that the bivariate model is the correct specification. The Wald test also indicated the high joint significance of the variables in both models.

Table 2 Bivariate Probit Analysis: The Effects of Technology-Exploration on the Degree of Novelty

\begin{tabular}{lll}
\hline & Model & High \\
\cline { 3 - 3 } & Low & \\
\hline Explanatory variable & & $0.351^{* * *}$ \\
CI & $1.52^{* * *}$ & $0.493^{*}$ \\
OUTRD & -0.023 & -0.33 \\
EXNT & 0.0018 & -0.0035 \\
INIPLI & -0.049 & \\
Control variable & & $0.135^{* * *}$ \\
R\&D intensity & 0.010 & $-0.060^{*}$ \\
Sizes & $-0.092^{*}$ & -0.0087 \\
GLOB & 0.0077 & -1.28 \\
Intercept & 0.69 & \\
$L R^{2} \sim X^{2}: \rho=0$ & $27.25^{* * *}$ & \\
Wald test of full model: & $802.3^{* * *}$ & \\
Log pseudo-likelihood & -600.427 & \\
Number of observations (period) & $1044(2005 \sim 2007)$ & \\
\hline$* 0.10, * * 0.05, * * *<0.01$ & &
\end{tabular}


Customer involvement has a positive and significant effect on the likelihood of achieving product innovation with both a low degree of novelty and a high degree of novelty $(\beta=1.52, p<0.01 ; \beta=0.351, p<0.01)$. Outsourcing $R \& D$ has no significant impact on the probability of achieving incremental innovation and a positive and significant effect on the likelihood of achieving more novel innovations $(\beta=0.493, p<0.1)$.

External networking and inward IP licensing have no significant impact on the probability of achieving product innovation, both with a low and a high degree of novelty.

The effect of the control variable of R\&D intensity on the likelihood of achieving innovation is only significant in the case of a high degree of novelty. Size has a negative and significant impact on the likelihood of achieving product innovation, both with a low and a high degree of novelty. Globalization has no significant impact on the likelihood of achieving product innovation, both with a low and a high degree of novelty as well.

\section{Discussion}

Manufacturing firms are subject to rapid technological changes and a constant need to innovate more quickly and in more novel ways compared to their competitors. Considering the firm's capacity, selecting the appropriate innovation activity is important for achieving product innovation. We investigated the effects of technology-exploration, specifically customer involvement, outsourcing $R \& D$, external networking, and inward IP licensing, on product innovation in Korean manufacturing SMEs. Product innovation performance is measured as radical and incremental innovation to gauge the degree of the novelty of product innovation. Our results show that technology exploration is crucial regarding whether a low or a higher degree of novelty is achieved in product innovation in manufacturing SMEs. Customer involvement has a positive impact on both incremental and radical innovation. Outsourcing R\&D has a positive impact on only radical innovation. Other practices have no impact on either incremental or radical innovation.

\section{Implication}

Our findings might offer several practical implications for the manufacturing SMEs that try to achieve incremental or radical innovations.

For the incremental innovation, capturing the needs of influential customers can help them realize new solution ideas [62], quickly identify market trends, and enhance new technology applications. In this process, Organizational filters and routines are deeply involved in satisfying customer needs [23]. Organizational filters are cognitive structures that screen out information unrelated to the organization's important tasks and help firms process consumer requests or complaints, channel them to manufacturing departments or distributors, and ensure that the current products meet consumer expectations as effectively as possible [63]. They develop organizational routines to carry out the repetitive tasks of manufacturing and distributing large volumes of their current products efficiently. They can maximize the utility of current technology for their customers and strive toward efficiently developing incremental innovations through these routines [64]. 
Our findings imply that customer involvement is also important for radical innovation in manufacturing SMEs. Radical innovation is the development of new products or services that yield much greater benefits to customer compared to those that use older products or services [23]. Customers contribute to radical innovation by actively participate in the process of the development of a new product as an inventor or co-producer of innovation [29]. Especially lead users provide a solution to customers' needs and are highly motivated to engage in innovative endeavors [62]. They contribute substantially to the development of highly innovative and commercially attractive products [29]. Nearly $70 \%$ of the sample firms in this study are manufacturing SMEs that supply components to other firms. Their customers are also manufacturing firms who are sensitive to market changes; thus, they want to be supplied with a component or product that can lead their market. They actively engage in the product development process by providing innovative ideas or opinions to suppliers and playing the role of the lead user in their industry, thus contributing to radical innovation.

Outsourcing $R \& D$ is also important for radical innovation. Research organizations (research institutes and universities) are important centers and valuable sources for creating and disseminating the scientific knowledge necessary to develop radically new products [65]. Because manufacturing SMEs focus on the development of new products through new external knowledge and technology from outsourcing R\&D organizations, Collaborations with research organizations may be an effective strategy to achieve radical innovation.

This study makes important theoretical contribution. In this research, we firstly classified innovation into levels of degree. By doing so, we could deduct necessary factors for each levels of innovation and empirically verified their relationships. For the innovation performance, antecedent researches mostly focused on measuring numbers of innovation, especially number of patent. This study proposed new way of measure innovation to differentiates from existing studies and provide possibility to verify innovation performance using probit or logit model.

\section{Limitation \& future research}

Our findings provide a better understanding of how much technology-exploration practices affect product performance in manufacturing SMEs. This research demonstrates an analysis related to product innovation of manufacturing SMEs; however, it did not classify sample manufacturing SMEs into groups in depth.

Although the data are reliable, our analysis may ignore the characteristics of each classified group according to the customer and product. Manufacturing SMEs need to know various types of customer-related information, such as their customer needs, preferences, purchasing procedures, and the procedures related to the distribution and sales access to the customers in various sample groups. A conclusion about the complex relationships between each classified category group and product innovation requires a longitudinal study, which should be undertaken in the future.

Competing interests

The authors declared that they have no competing interests. 
Received: 2 December 2015 Accepted: 7 June 2016

Published online: 04 July 2016

\section{References}

1. Teece DJ (1986) Profiting from technological innovation: implications for integration, collaboration, licensing and public policy. Res Policy 15(6):285-305

2. Chesbrough HW (2003) Open innovation: the new imperative for creating and profiting from technology. Harvard Business Press, Boston

3. Chesbrough HW, Vanhaverbeke, West J (2006) Open innovation: researching a new paradigm. Oxford University Press, London

4. Gassmann O (2006) Opening up the innovation process: towards an agenda. R\&D Manag 36(3):223-228

5. Nieto MJ, Santamaria L (2007) The importance of diverse collaborative networks for the novelty of product innovation. Technovation 27(6-7):367-377

6. Shin S, Lee M (2014) The effect of innovation activities on innovation performance according to the size of SMES in the field of electronics and communication industry. Soc Korea Ind Systs Eng 37(1):79-90

7. Hwang G-I (2003) A study on the present state and development plan of Korean small and medium sized firms. J manag Res Namseoul Univer 5:212-234

8. IMD (2011) The world competitiveness yearbook. IMD World Competitiveness Center, Lausanne

9. Freel MS (2000) Barriers to product innovation in small manufacturing firms. Int Small Bus J 18(2):60-80

10. Karlsson C, Olsson O (1998) Product innovation in small and large enterprises. Small Bus Econ 10(1):31-46

11. Nooteboom B (1994) Innovation and diffusion in small firms: theory and evidence. Small Bus Econ 6(5):327-347

12. Sivadas E, Dwyer FR (2000) An examination of organizational factors influencing new product success in internal and alliance-based processes. J Mar Sci 64(1):31-49

13. Vossen RW (1998) Relative strengths and weaknesses of small firms in innovation. Int Small Bus J 16(3):88-94

14. Srinivasan R, Lilien GL, Rangaswamy A (2002) Technological opportunism and radical technology adoption: an application to e-business. J Mar Sci 66(3):47-60

15. Van de Vrande V, De Jong JPJ, Vanhaverbeke W, De Rochemont M (2009) Open innovation in SMEs: trends, motives and management challenges. Technovation 29(6-7):423-437

16. Dougherty D, Hardy C (1996) Sustained product innovation in large, mature organizations: overcoming innovation-to-organization problems. Acad Manage J 39(5):1120-1153

17. Economico, O.d.C.y.D. (1997) Oslo Manual: Proposed Guidlines for Collecting and Interpreting Technological Innovation Data. Statistical Office of the European Communities. OECD Publishing

18. Economico, O.d.C.y.D. (2005) Oslo Manual: Proposed Guidelines for Collecting and Interpreting Innovation Data. OECD, Eurostat

19. Freeman C, Soete $L$ (1997) The economics of industrial innovation. Routledge.

20. Chandy RK, Tellis GJ (1998) Organizing for radical product innovation: the overlooked role of willingness to cannibalize. J Mark Res 34:474-487

21. Marsili O, Salter A (2005) Is innovation democratic? skewed distributions and the returns to innovation in Dutch manufacturing. Econ New Technol Innov 14(1-2):83-102

22. Geroski P, Machin S, Van Reenen J (1993) The profitability of innovating firms. RAND J Econ 24(2):198-211

23. Chandy RK, Tellis GJ (2000) The incumbent's curse? incumbency, size, and radical product innovation. J Mar Sci 64:1-17

24. Varadarajan R (2009) Outsourcing: think more expansively. J bus res 62(11):1165-1172

25. Barczak G (1995) New product strategy, structure, process, and performance in the telecommunications industry. J Prod Innovation Manag 12(3):224-234

26. Gales L, Mansour-Cole D (1995) User involvement in innovation projects: toward an information processing model. J Eng Technol Manag 12(1-2):77-109

27. Lundkvist A, Yakhlef A (2004) Customer involvement in new service development: a conversational approach. Manag Serv Qual 14(2/3):249-257

28. Rothwell R, Freeman C, Horlsey A, Jervis VTP, Robertson AB, Townsend J (1993) SAPP HO updated-project Sappho phase II. Res Policy 22(2):110

29. Lettl C, Herstatt C, Gemuenden HG (2006) Users' contributions to radical innovation: evidence from four cases in the field of medical equipment technology. R\&D Manag 36(3):251-272

30. Dahl DW, Moreau P (2002) The influence and value of analogical thinking during new product ideation. J Mark Res 39(1):47-60

31. Van De Vrande V, Lemmens C, Vanhaverbeke W (2006) Choosing governance modes for external technology sourcing. R\&D Manag 36(3):347-363

32. Birkinshaw J, Van Basten Batenburg R, Murray G (2002) Corporate venturing: the state of the art and the prospects for the future, 390th edn. London Business School, London, pp 64-70

33. Gompers P, Lerner J (2000) The determinants of corporate venture capital success: organizational structure, incentives, and complementarities. University of Chicago Press, Chicago, IL

34. Chesbrough HW (2002) Making sense of corporate venture capital. Harv Bus Rev 80(3):90-99

35. Dushnitsky G, Lenox MJ (2005) When do incumbents learn from entrepreneurial ventures?: corporate venture capital and investing firm innovation rates. Res Policy 34(5):615-639

36. Schildt HA, Maula MVJ, Keil T (2005) Explorative and exploitative learning from external corporate ventures. Entrep Theory Pract 29(4):493-515

37. Gomes-Casseres B (1997) Alliance strategies of small firms. Small Bus Econ 9(1):33-44

38. Chen WH, Chiang AH (2011) Network agility as a trigger for enhancing firm performance: a case study of a high-tech firm implementing the mixed channel strategy. Ind Mark Manag 40(4):643-651 
39. Mäläskä M, Saraniemi S, Tähtinen J (2011) Network actors' participation in B2B SME branding. Ind Mark Manag 40(7):1144-1152

40. Nelson RR, Winter SG (1982) An evolutionary theory of economic change. Belknap, Cambridge

41. Ahuja G, Katila R (2001) Technological acquisitions and the innovation performance of acquiring firms: A longitudinal study. Strategic Management Journal 22(3):197-220

42. Cohen WM, Levinthal DA (1990) Absorptive capacity: a new perspective on learning and innovation. Adm Sci Q 35(1):128-152

43. O'Malley SVL, Hart S (2011) Roles, role performance, and radical innovation competences. Ind Mark Manag 40(6):952-966

44. Hsuan J, Mahnke V (2011) Outsourcing R\&D: a review, model, and research agenda. R\&D Manag 41(1):1-7

45. Harmancioglu N (2009) Portfolio of controls in outsourcing relationships for global new product development. Ind Mark Manag 38(4):394-403

46. Kotabe M, Mol MJ, Murray JY (2008) Outsourcing, performance, and the role of e-commerce: a dynamic perspective. Ind Mark Manag 37(1):37-45

47. Harris A, Giunipero LC, Hult GTM (1998) Impact of organizational and contract flexibility on outsourcing contracts. Ind Mark Manag 27(5):373-384

48. Rogers M (2004) Networks, firm size and innovation. Small Bus Econ 22(2):141-153

49. Caloghirou Y, Kastelli I, Tsakanikas A (2004) Internal capabilities and external knowledge sources: complements or substitutes for innovative performance? Technovation 24(1):29-39

50. Song M, Van Der Bij H, Weggeman M (2005) Determinants of the level of knowledge application: a knowledge based and information processing perspective*. J Prod Innovation Manag 22(5):430-444

51. Tsai KH, Wang JC (2007) Inward technology licensing and firm performance: a longitudinal study. R\&D Manag $37(2): 151-160$

52. Chatterji D (1996) Accessing external sources of technology. Res Technol Manag 39(2):48-56

53. Lugones G, Peirano F (2004) Proposal for an annex to the Oslo manual as a guide for innovation surveys in less developed countries Non-members of the OECD. Centro REDES/RICYT, Buenos Aires

54. Hagedoorn J, Cloodt M (2003) Measuring innovative performance: is there an advantage in using multiple indicators? Res Policy 32(8):1365-1379

55. Lakemond N, Berggren C (2006) Co-locating NPD? the need for combining project focus and organizational integration. Technovation 26(7):807-819

56. Liker JK, Collins PD, Hull FM (1999) Flexibility and standardization: test of a contingency model of product design-manufacturing integration. J Prod Innovation Manag 16(3):248-267

57. Keupp MM, Gassmann O (2009) Determinants and archetype users of open innovation. R\&D Manag 39(4):331-341

58. Negassi S (2004) R\&D co-operation and innovation a microeconometric study on French firms. Res Policy 33(3):365-384

59. Simon H (1996) Hidden champion. Harvard Business School Press, Boston

60. Aldrich JH, Nelson FD (1984) Linear probability, logit, and probit models. Sage, Beverley Hills

61. Greene WH, Zhang C (2003) Econometric analysis. vol 5, Upper Saddle River, Prentice hall New Jersey

62. Von Hippel E, Thomke S, Sonnack M (1999) Creating breakthroughs at 3 M. Harv Bus Rev 77:47-57

63. Hannan MT, Freeman J (1977) The population ecology of organizations. Am j soc 82(5):929-964

64. Henderson R (1993) Underinvestment and incompetence as responses to radical innovation: evidence from the photolithographic alignment equipment industry. RAND J Econ 24(2):248-270

65. Spencer JW (2003) Firms' knowledge sharing strategies in the global innovation system: empirical evidence from the flat panel display industry. Strat Manag J 24(3):217-233

\section{Submit your manuscript to a SpringerOpen ${ }^{\circ}$} journal and benefit from:

- Convenient online submission

- Rigorous peer review

- Immediate publication on acceptance

- Open access: articles freely available online

- High visibility within the field

- Retaining the copyright to your article

Submit your next manuscript at $>$ springeropen.com 